\title{
Does Foreign Land Acquisition Deprive Per Capita Income in Africa?
}

\author{
Adeyemi A. Ogundipe ${ }^{1, *} \&$ Samuel O. Egbetokun ${ }^{2}$ \\ ${ }^{1}$ Department of Economics and Development Studies, Covenant University, Ota, Ogun State, \\ Nigeria \\ ${ }^{2}$ Department of Business Education, School of Vocational and Technical Education, \\ Adeniran Ogunsanya College of Education, Lagos, Nigeria \\ *Corresponding author: Department of Economics and Development Studies, Covenant \\ University, Ota, Ogun State, Nigeria. Tel: 234-816-192-7372. E-mail: \\ ade.ogundipe@covenantuniversity.edu.ng; yemi_keke2001@yahoo.com
}

Received: January 14, 2014 Accepted: February 26, 2014 Published: October 27, 2014

doi:10.5296/rae.v6i4.4911 URL: http://dx.doi.org/10.5296/rae.v6i4.4911

\begin{abstract}
This study investigates the implications of large scale foreign land acquisitions on per capita income in Africa. It employs data from World Development Indicators, World Governance Indicators and World Trade Indicators on key variables such as arable land per person, agricultural land as percentage of land area, net food import, regulatory quality, among others (1995-2012) on selected African countries where instances of foreign land deals have been reported. The study formulates empirical models that draw from institutional development theory, which was estimated using Fixed Effects (FE) and Generalised Method of Moments (GMM) techniques in order to handle the issues of country-specific effects and endogeneity. The results from the empirical analysis show that agricultural land influences per capita income significantly. It hereby implies that as more agricultural land are cultivated; the wellbeing of the populace is likely to be enhanced primary through increased income for farmers, increase in real money income for non-farmers, drastic reduction in food inflation and foreign exchange gains for the government. The results of the study suggest the need for controlling the issue of massive foreign land deals through viable institutional framework, though there is need for foreign investment in Africa's agricultural sector but sound institution is pertinent in order to avoid rent seeking behaviour among stalk holders.
\end{abstract}

Keywords: Agriculture; Per capita income; Institutional quality; Land deals

JEL Codes: F21; R52; Q15; Q18 


\section{Introduction}

The study is motivated essentially by large scale foreign land deals in African countries and other developing countries that have been reported in recent years. One of the driving forces has been attributed to the presumed availability of land in these regions. Africa and Latin America is said to have about 80 percent of world reserves of agricultural land with Angola, Democratic Republic of Congo and Sudan being among the seven countries in Africa and Latin America that account for about half of the world land reserves (IFPRI, 2009). This, among other factors, has made Africa the most targeted region, which has recorded more than half of the foreign land deals in the world. From available data, there have been incidences of large scale foreign acquisitions of land across African countries. Over 2,492,684 hectares of land has been acquired in Ethiopia, Ghana, Madagascar, Mali and Sudan. This represents almost half of the arable land in United Kingdom and thrice the arable land of Norway. In Sudan and Ethiopia alone, the figures are about 3.9 million and 1.2 million hectares, respectively (Cotula, Vermeulen, Leonard and Keeley, 2009).

The implications of foreign land deals can be far-reaching; though some argue that there are opportunities of increasing capital inflows, government revenue, among others, for the host countries. However, there are serious challenges that the foreign land deals may portend. For African countries especially those with difficulties in feeding their teaming population, leasing/selling agricultural lands to foreign investors who will used them to produce and export food to rich countries (in most cases their home countries to meet their own food requirements) will worsen the issue of food security. An example is the attempted South Korea Daewoo and Saudi Arabia farming investment in Madagascar and Sudan, respectively (REF). The agricultural products produced by foreign farmers would be exported to their home countries leaving the recipient countries to lose in two ways: land resources and availability of food products in domestic economy. Another implication is the displacement of small scale farmers from their major means of livelihood due to their low bargaining power and inadequate knowledge. In most instances they wake up to hear of foreign land deals made by their governments without their inputs.

According to Smaller and Mann (2009), a number of key factors triggered the recent surge of interest in investment in agricultural land. The short-term factors include a response by food-importing countries to the high global food prices in 2008, and the subsequent decision by leading commodity exporters to impose export restrictions on key staple crops. At least 25 countries imposed export bans or restrictions in 2008, including India, Russia, Argentina and Vietnam. High oil prices in 2007 and early 2008 triggered further interest by the private sector to acquire land for energy crops, and helped promote interest in receiving agricultural investment to reduce the costs of imported foods into developing countries. Finally, financial investors, searching for new sources of investment outside the banking and property sector, saw opportunities in agricultural land markets, expecting the value of both food and fertile land to increase as the long and short-term factors continue to grow.

Furthermore, vertical integration (foreign versus domestic) in agricultural production, processing and distribution will result in more concentrated power to the agribusiness and 
agricultural trade, with many possible adverse outcomes emanating from pricing as well as supply chain issues. Potential adverse effects on the environment may occur due to large-scale fertilizer and chemical applications, which has risk of reducing agricultural production and, by extension, agricultural export in the host countries. It is this recognition that the seven Principles for Responsible Agricultural Investments was initiated by the World Bank, Food and Agricultural Organization (FAO), United Nations Conference on Trade and Development (UNCTAD), and International Fund for Agricultural Development (IFAD), which was backed by the 2010 G8 Summit in Ontario. This is crucial as great proportion of African population (over 70 percent in some countries) dwell in the rural areas where their major livelihood depend on land for agricultural purposes. The export of most African countries depend largely on commodity products that require land for production, especially agriculture, mining and quarrying, which will be adversely affected by foreign land deals (Osabuohein, Ogundipe and Efobi, 2013)

The main research issue of this study is that major land deals in Africa with long duration (about 100 years) and sales of large acreage are made in countries known to have weak institutional quality and poor land governance. World University News recently reports that foreign land acquisitions in Africa (especially as hedge fund) is about 60 million hectares of in about seven African countries. A key issue in the report is that in many of the countries the deals were made for the purpose of securing rights to valuable natural resources and it calls research efforts that will enlighten the African populace on the issue (Moodie, 2011). This study is a response to it, among others. To achieve its objectives, the study employs data from World Development Indicators, World Governance Indicators and World Trade Indicators on key variables such as arable land per person, agricultural land as percentage of land area, net food import, regulatory quality, among others (1995-2012) on selected African countries where instances of foreign land deals have been reported. The study formulates empirical models that draw from institutional development theory, which will be estimated using Fixed Effects (FE) and Generalised Method of Moments (GMM) techniques with a view to handling the issues of country-specific effects and endogeneity.

Foreign land investors do promise employment and infrastructural development but they often fail to deliver on their promises as there are no strong institutional machineries to drive it. The study suggests the need for African governments to clarify the kind of investment, how the returns from the land deals are to be distributed. The assessment of social and environmental impacts as well as transparency in decision-making and compensation of displaced land users are equally suggested. Though the issue of foreign land acquisition is not utterly bad but this study posits that the recipient countries need to make adequate assessment of investment and development plans when such transactions are to be made, which can be done by setting up committee on land acquisition charged with the responsibility of consultation, implementation and compensation.

The rest part of the study is structured in sections. The next section presents some background facts on the issues, which is followed by literature review. Sections 4 and 5 contain the method of analysis and empirical results respectively, while the last section concludes. 


\section{Some Background Facts}

The issues surrounding land has been central to policy debates among media reporters, scholars, policy-makers, urban managers partly because it is a peculiar good and it's increasing relative scarcity to fast population growth and rapid urbanization. In the past few years, hectares of agricultural lands have been acquired by foreign investor, which has been reported to have more than the farmland of France. Most of the land acquisitions have happened outside public scrutiny, which have generated intense debates especially in the media (Fian, 2010). The report from World University News has it that foreign land acquisitions in Africa by foreign investors (especially in USA who want to use them as hedge fund) amount to about 60 million hectares of in about seven African countries, namely: Ethiopia, Mali, Mozambique, Sierra Leone, Sudan, Tanzania, and Zambia. One of the major issue in the report is that in many of these countries the deals were made for the express purpose of securing rights to valuable natural resources such as oil, timber, water and arable land and they call on African researchers to engage in research efforts that will enlighten the African populace on the issue (Moodie, 2011).

One of the implications of land deals in Africa will be the displacement of local farmers from their ancestral land by turning valuable agricultural land for industrial use. This issue is a plight of Africa endowment as farmland is not only central to export income of most Africa countries (as the bulk, over 90 percent of Africa export goods are commodity in nature) but highly significant to rural livelihood and national food security. This is given the fact that about 75 percent of the world's poor people live in rural areas (it is more than that in most African countries), and most are involved in agriculture (Cotula et al., 2009). With the understanding that agriculture remains fundamental to economic growth, poverty alleviation, and environmental sustainability; the issue of foreign land acquisition would endanger the prospect of developing Africa countries especially in curbing poverty. The up-surging food crisis, growing human and environmental pressures has culminated into high foreign interest in farmland, which generates the worries over food security (Moodie, 2011).

The major frontiers of the acquisition in farmland abroad deals are food-importing countries with land and water constraints but rich in capital, such as Gulf States. Also, Countries such as China, South Korea and India with large populations and food security concerns seeks opportunities to produce food for their teeming population abroad. The present land acquisition in Africa would further increase the incidence of food in security in the region. At a time when the food aid convention is been instituted for seeking aid to improve the provision of reliable amount of food supplies to developing countries, foreign land acquisition will dwindling the potential of adequate food production in Africa. With the increasing upwards shot in food prices since 2007, falling food aid to Africa and the incessant rise in land acquisition, the incidence of hunger tends to rise in the region, which results into much hunger (IFPRI Policy Brief, 2009).

Foreign land acquisition is majorly targeted toward the developing countries where production costs are believed to be lower and where land, water and other natural resources are relatively in abundance. Other factors that influence such acquisitions include climate 
conditions for preferred staple crops, desire for food security of investors' countries, for the production of biofuel crops, and increased land arbitrage opportunities. In most cases, investors are been lured to invest in land acquisition in Africa by high returns promised them by hedge funds and private equity firms. An instance is the investment in land acquisition in Africa by two prestigious America Universities (Harvard and Vanderbilt endowment investment). These investments were motivated by relatively cheap land cost in Africa where the cost of agri-land is about one-seventh of the price of similar land in Argentina, Brazil and America. At times the governments, directly or indirectly, are involved in the negotiations for arable land leases, concessions or purchases. Some governments seek to secure food supplies through contract farming, investment in rural and agricultural infrastructure such as irrigation system and roads (Moodle, 2011).

The recent transnational land deals are partly an effect of economic valuation of land and water as signalled by higher land prices. The food price crisis has increased compensation for land and water resources for agriculture, making farmland prices raised across the world. For instance, in 2007, there was 16 percent increase in farmland prices in Brazil, 31 percent in Poland and 15 percent in Mid-Western United States (IFPRI, 2009).

To take the aforementioned issues further, this study presents some of the major land deals reported in some African countries in Table 1. The land deals reported involved both private foreign firms acquiring land in Africa as well as those that involved governments for the period 2006-2009. Apart from Djibouti, Egypt, Libya and South Africa that have reported to be involved in land deal in Malawi, Mali, Sudan and Congo, Democratic Republic, respectively, all other land deals reported in Table 1 involved countries in the Middle East (Qatar, UAE, Kuwait, Saudi Arabia), Asia (Jordan, South Korea, China, India), Europe (Sweden, Germany, UK) and America (USA).

As reported in Table 1, the least land deal in terms of acreage was 5,500 hectares; many are in million hectares. This gives some concern given that the acreage of land in any country is limited in supply, which implies that any foreign acquisition reduces the available land for agricultural purpose. Furthermore, with regards to the purpose of the land deals in Table, it can be observed that majority of them are for growing food crops such as rice, maize, wheat, sweet sorghum. Others for producing crops needed for bio-fuels, crops for feeding animals, and for investment (hedge fund). This denotes the fact that foreign land acquisition is driven by the need to meet food security and investment that will yield future returns. To this end, this study will focus on the countries in Africa that the land deals are reported. As informed by Table 1, they are 16 countries, which will be used in the empirical aspect of the study. 


\section{Macrothink}

Research in Applied Economics

ISSN 1948-5433

2014, Vol. 6, No. 4

Table 1. Overseas Land Deals Africa to Secure Food Supplies (2006-2009)

\begin{tabular}{|c|c|c|}
\hline Target country & Investor's country & Nature of Land Deals \\
\hline Angola & Lonrho (UK) & $\begin{array}{l}25000 \text { ha leased for rice. Lonrho is negotiating for a further } 125,000 \text { ha in } \\
\text { Mali and Malawi. }\end{array}$ \\
\hline Cameroun & Unknown company (China) & 10,000 ha secured for rice. \\
\hline Congo, DR & China (ZTE International) & 2-8 million ha secured for biofuel oil palm plantation. \\
\hline Congo,DR & $\begin{array}{l}\text { Agriculture South Africa (South } \\
\text { Africa) }\end{array}$ & 10 million ha offered to farmers' union. \\
\hline Egypt & Jenat (Saudi Arabia) & 10,000 ha secured for barley, wheat, and livestock feed. \\
\hline Ethiopia & Flora Ecopower (Germany) & 13,000 ha secured for biofuel crops; contract farming arrangement. \\
\hline Ethiopia & Sun Biofuel (UK) & Land secured for Jatropa (biofuel). \\
\hline Ethiopia & India & $\begin{array}{l}\text { US } \$ 4 \text { billion invested, including agriculture, flower growing and sugar } \\
\text { estates. }\end{array}$ \\
\hline Ethiopia & $\begin{array}{l}\text { Unknown private investors (Saudi } \\
\text { Arabia) }\end{array}$ & Land leased in exchange for US\$100 million investment. \\
\hline Kenya & Qatar & $\begin{array}{l}40,000 \text { ha leased for fruit and vegetable cultivation in exchange for } \\
\text { funding US } \$ 2.3 \text { billion port. }\end{array}$ \\
\hline Madagascar & Daewoo (South Korea) & 1.3 million ha secured for maize. \\
\hline Malawi & Djibouti & Unknown area of farm land leased. \\
\hline Mali & Libya & 100,000 ha leased for rice. \\
\hline Mozambique & Skebab (Sweden) & 100,000 ha secured for biofuel crops. \\
\hline Mozambique & China & $\begin{array}{l}\text { US } \$ 800 \text { million investment to expand rice production from } 100,000 \text { to } \\
500,000 \text { metric tons; political opposition to deal. }\end{array}$ \\
\hline Nigeria & Trans4mation Agrictech Ltd (UK) & 10,000 ha secured. \\
\hline Sudan & Egypt & Land secured to grow 2 million tons of wheat annually. \\
\hline Sudan & Jordan & 25000 ha secured for livestock and crops. \\
\hline Sudan & Kuwait & 'Giant' strategic partnership; no further information. \\
\hline Sudan & Qatar & Joint holding company setup to invest in agriculture. \\
\hline Sudan & $\begin{array}{l}\text { Saudi Arabi (Hail Agricultural } \\
\text { Dev. Co) }\end{array}$ & $\begin{array}{l}9,200-10,117 \text { ha leased for wheat, vegetables and animal feed: } 60 \% \text { paid } \\
\text { by Saudi government. }\end{array}$ \\
\hline Sudan & South Korea & 690,000 ha secured for wheat. \\
\hline Sudan & United Arab Emirates (UAE) & 378,000 ha total invested in by UAE. \\
\hline Sudan & $\begin{array}{l}\text { UAE (Abu Dhabi fund for } \\
\text { development) }\end{array}$ & $\begin{array}{l}30,000 \text { ha secured for corn, alfalfa, and possibly wheat, potatoes, and } \\
\text { beans. }\end{array}$ \\
\hline Sudan & Jarch capital (USA) & 400,000 ha in Southern Sudan signed with local army commander. \\
\hline Tanzania & CAMS Group (UK) & 45,000 ha purchased for sweet sorghum. \\
\hline Tanzania & Sun Biofuels (UK) & 5,500 ha secured for Jatropa (biofuel). \\
\hline Tanzania & Saudi Arabia & 500,000 ha requested for lease. \\
\hline Tanzania & China (Chongqing seed corp) & 300 ha secured for rice. \\
\hline Zambia & China & 2 million ha requested for Jatropha (biofuel). \\
\hline
\end{tabular}

Note: In addition to the countries in this Table, land deals have also been reported in Ghana and Sierra Leone Source: Compiled from IFPRI Policy (2009) Brief 13. 


\section{Literature Review}

The issue of foreign land acquisition is gaining interesting in recent times. Though they have been increased media reports, there is dearth academic work especially those with empirical analysis. Modie (2011) gives the indication that in many African countries foreign land acquisitions are made for purpose of securing rights to valuable natural resources such as oil, timber, water and arable land. This is crucial because land is not only critical to life support for farmers but has been one of the most important assets that can be a principal source of wealth and power (Mattingly, 1993). As a result, literature exists on impacts of land rights, access to and tenure security on economic development, social advance and justice, poverty reduction, and political implications (Larbi et al., 2004; Misra, 1991; Nyambara, 2001; Skyner, 2001; Barbier, 1997).

The increased food prices especially basic foods like rice, wheat and maize in 2007 and 2008 global food crisis strengthen the attractiveness of investment in agricultural production (Cotula et al., 2009), and thus created a positive feedback mechanism that further increased the interest in land (Fiirs and Reeberg, 2010). The prices of maize and wheat almost doubled from 2003 to 2008 while prices of rice tripled in just a few months in early 2008 (Headey 2010, IFPRI 2009)

Though foreign land deal is a global issue, but the specific interest in poor developing economies, especially Africa in recent time has attracted the attention of media and scholars (Friis and Reeberg, 2010). International investment in Africa's agricultural production should be a welcome initiative but the changing economy and climate condition has changed the seriousness of land use. The current land deals are driven by the desire to secure land rights, fresh water for domestic food and meet energy needs (Smaller and Mann 2009; UN 2010).

Foreign land deals have some implications on poverty. The labour perspective to the issue of land acquisition relates the predicament of people whose labour is not needed by global capitalist system. In most land grabbing states, the anticipated transition from the farm to factory has not taken place and education offers no solution, as vast numbers of educated people are unemployed. Except jobs are created, any program that displaces rural people of their foothold on the land would usually be contented. However, World Bank report (2011) argues that large-scale land acquisition can be a vehicle for poverty reduction through three main mechanisms: the generation of employment for wage workers; new opportunities for contract farmers; and payments for the lease or purchase of land. Land purchases have not resulted in the promised benefits even though most land deals are on the premise that they will provide employment opportunities. This contrary view has been observed by Tania (2011) that poverty reduction is a very unlikely result from land deals.

Most acquired lands are usually close to Africa rivers, railways, and roads probably for ease transportation of produce to home countries. This seems represents a win for investors but a loss to the poor communities. In this regards, the recipient government need to protect sectors which are absolutely essential for countries' and peoples' self-determination, food security and food sovereignty. In order to lessen poverty resulting effect of land grab, the recipient countries governance should envision the local peoples' access to land and resources which 
serve as a pre-condition for a decentralized, sustainable and autonomous agriculture. There is need to analyse the human right framework in the ongoing land grabbing based on the rights to adequate food, to adequate housing, to adequate standard of living including access to resources, the right to work and the right to information and political participation (Vermeulen and Cotula, 2010).

The rights of indigenous people needs to be preserved, the right to self-determination and the right not to be deprived of one's means of subsistence. FIAN international applied this framework of rights in handling cases of land grabbing in Kenya and Mozambique. In 2008, the government of Qatar acquired 40,000 ha of high potential land in Kenya to produce horticultural products for Qatar. The exact location of the project was not officially declared and the project was surrounded with secrecy; the news of this alienation of land and export of food crops was revealed when the government declared a national food shortage emergency, as Kenya experienced severe droughts and poor harvest. The second project in Kenya involved a public-private partnership on sugarcane monoculture. Mumias sugar company Ltd (largest sugar company in Kenya) and the state-run Athi River Development Authority (TARDA) proposed to acquire 16,000 hectares of land to be turned into sugar cane plantation for agrofuels. These deals if successfully conducted would result into displacement of tens of thousands of peasant farmers currently using the land for food crops such as Cassava, Maize, Vegetables, Beans and Mango; likewise about 2000 pastoralist will also suffer severely as the land has been used as grazing for their cattle for generations (Fian Report, 2010).

According to Klaus and Derek, 2011; the current wave of land acquisition in most developing economies is a strategy of transferring foreign burden as most developing countries eagerness to attract investors in an environment where state capacity is weak, property rights ill-defined, and regulatory institutions starved of resources could lead to projects that fail to provide benefits, for example, because they are socially, technically, or financially nonviable. Such failure could result in conflict, environmental damage, and a resource curse that, although benefiting a few, could leave a legacy of inequality and resource degradation.

Another study showing the extent of burden transfer conducted by Food First Information and Action Network International revealed a similar case of deprivation of rural means of subsistence is the case of Yala swamp wetland acquisition in Kenya. The land provides major ecological and hydrological functions and serves as the major source of livelihoods for the neighbouring communities. The land was in trust under the custody of the Siaya and Bondo county councils. The land is densely populated with about half a million people; the local people accessed the land for various daily activities. In 2003, Dominion Farm Ltd (a subsidiary of Dominion Group of companies in USA) acquired 6,900 ha of the 17500 ha wetland for the duration of 25 years and eventually cover the entire swamp region of 17500 hectares.

The Massingir case in Mozambique was not an exception; it contains a projected sugar cane plantation of 30000 ha acquired by the British company Bio-Energy Africa under 50 year contract meant to provide ethanol to South Africa. The land affected represents the main source of livelihood of the Massingir communities and used for livestock raising, charcoal 
production, and subsistence farming. The cases of land grabbing in Africa severely impacts on peoples' livelihood and lack no proper consultation of local communities, as well, is the lack of comprehensive impact assessment prior to initiation land project. This has resulted into authorities breached of human rights obligations towards the local people and could further result in resistance by peasant farmers over the take-over of their land. Land foretimes has been an object of conflict among nations, tribes and communities culminating into several civil wars; the on-going grabbing experience will definitely not result less (Fian Report, 2010).

The Philippines blocked a land contract with China because of serious concerns about its terms and legal validity, as well as about its impact on local food security. Mozambicans have resisted the settlement of thousands of Chinese agricultural workers on leased labour in the new agricultural investments. The weak governance in many of these Africa Countries have paved way for most successful land deals, the land negotiation in Madagascar with Daewoo logistic corporation to lease 1.3 million hectares for maize and oil palm reportedly played a role in the political conflicts that led to the overthrow of the government in 2009 (Joachim and Ruth, 2009)

The availability of uncultivated land in many countries possessed a development challenge before the food price of 2008. There is need for more and better investment in agriculture as 75 percent of the world's poor are rural and mostly engaged in farming; the improved investment would help to reduce poverty, increase economic growth and promote environmental sustainability. The need for the investment is expedient as there were only 830 million hungry people before the food price rise but after the human history has recorded over a billion people going to bed hungry each night (World Bank Report. 2009). Though additional investments in agriculture in the developing countries is needed and should be welcome in principle but the manner of such land acquisition have resulted in opposition in some countries. With the changing global economic context, the agricultural sector clearly requires more investments due to the urgent need for greater development in rural areas and the fiscal inability of the developing country governments to provide the necessary infusion of capital, large-scale land acquisitions can be seen as an opportunity for increased investment in agriculture.

There exist a dichotomy in the existing literature, as some scholar perceived the foreign involvement in Africa's agriculture as a major threat to the livelihoods of the local poor (Cotula et al., 2009, Fian report 2011) while others see economic opportunity for the local communities that could benefit from the income generated from leasing or selling of the land (Gorgen et al., 2009). The favourable side of such investment list possible benefits for the rural poor, these benefits include: the creation of a potentially significant number of farm and off-farm jobs, development of rural infrastructure, and poverty-reducing improvements such as construction of schools and health posts. Other possible positive spill-over include resources for new agricultural technologies and practises, as well as future global price stability and increased production of food crops that could supply local and national consumers in addition to overseas consumers. 


\section{$\triangle$ Macrothink}

The unpleasant side of land acquisitions embodied threats that the land acquisition present to peoples' livelihoods and ecological sustainability (Braun and Meinzen-Dick 2009). Though some of the land lease agreement promised investment in rural development, the deals are usually not in equal terms between the investors and local communities due to the higher bargaining power the investor possess, usually supported host state or local elites in negotiating these agreements. The displaced land owners cannot favourably negotiate such powerful national and international agents likewise cannot enforce agreements if the foreign investors fail to comply with the promised jobs and local facilities (Li, 2011). This unequal dealing power originating from weak governance has perpetually placed the livelihood of the poor at risk.

Institutional gaps at the country level can be immense. Too often, they have included a lack of documented rights claimed by local people and weak consultation processes that have led to uncompensated loss of land rights, especially by vulnerable groups; a limited capacity to assess a proposed project's technical and economic viability; and a limited capacity to assess or enforce environmental and social safeguards.

\subsection{Land and institutions}

The metaphor "good institutions, better economic development", can be situated in the light of foreign land deals. This is because institutional quality has been noted to play important role in managing economic affairs. The seminal work of North fostered this idea, following the fact that it is becoming increasingly obvious that economic agents engaged in economic transactions are influenced principally by institutions among others (Natal, 2001; Meon and Sekkat, 2008; Osabuohien, 2011).

The quality of institutions in a country can create choices that can affect transactions and production costs. More so, institutions matter as it creates policies in an economy that will be relevant for securing property rights. This is in congruent to the development and efficient use of resources for economic growth and development (Cavalcanti et al., 2008). In other words, inappropriate institutional arrangements and policies in a country can lead to sub-optimal economic performance (Temple, 1999).

Relating this with land deals in Africa, land governance and deals will depend to a considerable extent, on the prevailing institutional quality in the concerned countries. This is based on the LaPorta et al., (1999) and Natal (2001) backdrop that economic activities engaged by individuals can be determined by some social and legal relationships existing among them. In this wise, there is the need to understand how and why individuals engage in a contract; and how individuals govern collective actions. 
Table 2. Indicators of land, food security and institutional quality in selected Countries

\begin{tabular}{lllllllllllll}
\hline & & \multicolumn{3}{c}{ arlandp } & \multicolumn{2}{c}{ agrivalu } & \multicolumn{2}{c}{ Net food export } & \multicolumn{2}{c}{ RQ } & \multicolumn{3}{c}{ PHR } \\
\cline { 2 - 11 } $\mathbf{s / n}$ & Country & 2000 & $\mathbf{2 0 1 0}$ & 2000 & $\mathbf{2 0 1 0}$ & $\mathbf{2 0 0 0}$ & $\mathbf{2 0 1 0}$ & $\mathbf{2 0 0 0}$ & $\mathbf{2 0 1 0}$ & 2000 & $\mathbf{2 0 1 0}$ \\
\cline { 2 - 11 } 1 & Angola & 0.22 & 0.19 & 13.03 & 6.64 & -356.20 & -1148.57 & 5.90 & 16.90 & 25.50 & 38.82 \\
2 & Cameroon & 0.39 & 0.32 & 25.33 & 19.47 & 115.36 & 78.43 & 26.30 & 26.10 & 37.86 & 32.97 \\
3 & DRC & 0.14 & 0.11 & 47.18 & 42.47 & -182.54 & -486.15 & 1.00 & 5.30 & 20.11 & 31.18 \\
4 & Egypt & 0.04 & 0.04 & 17.11 & 13.22 & -2474.65 & -3487.00 & 15.60 & 21.30 & 30.11 & 33.57 \\
5 & Ethiopia & 0.16 & 0.18 & 52.56 & 43.83 & -105.29 & -109.07 & 12.70 & 19.80 & 42.60 & 32.89 \\
6 & Ghana & 0.20 & 0.18 & 40.23 & 29.05 & 357.23 & 471.06 & 47.30 & 55.00 & 67.41 & 67.41 \\
7 & Kenya & 0.16 & 0.14 & 31.23 & 21.05 & -196.89 & -243.92 & 35.00 & 50.70 & 53.00 & 54.81 \\
8 & Madagascar & 0.20 & 0.16 & 30.58 & 24.81 & -38.19 & -81.28 & 21.50 & 41.50 & 71.53 & 58.20 \\
9 & Malawi & 0.23 & 0.21 & 35.58 & 30.11 & -47.23 & 147.34 & 44.40 & 38.60 & 54.82 & 50.60 \\
10 & Mali & 0.45 & 0.39 & 46.47 & 36.54 & -55.12 & -155.44 & 37.60 & 40.60 & 58.22 & 57.11 \\
11 & Mozambique & 0.23 & 0.20 & 30.84 & 30.47 & -157.31 & -275.43 & 36.60 & 35.30 & 64.62 & 57.07 \\
12 & Nigeria & 0.25 & 0.25 & 49.00 & 33.00 & -839.68 & -1964.84 & 18.00 & 29.50 & 45.84 & 37.49 \\
13 & Sierra leone & 0.12 & 0.17 & 61.80 & 50.21 & -128.15 & -109.31 & 9.30 & 7.20 & 48.02 & 52.33 \\
14 & Sudan & 0.50 & 0.48 & 46.35 & 26.25 & 135.26 & -745.62 & 7.80 & 7.20 & & \\
15 & Tanzania & 0.27 & 0.22 & 33.76 & 29.71 & -262.38 & -343.14 & 37.10 & 38.20 & 63.43 & 56.93 \\
16 & Zambia & 0.53 & 0.43 & 21.14 & 18.95 & -138.71 & -52.84 & 49.30 & 41.10 & 46.81 & 54.57 \\
& Average & $\mathbf{0 . 2 6}$ & $\mathbf{0 . 2 3}$ & $\mathbf{3 6 . 1 4}$ & $\mathbf{2 8 . 4 9}$ & $\mathbf{- 2 7 3 . 4 1}$ & $\mathbf{- 5 3 1 . 6 4}$ & $\mathbf{2 5 . 3 4}$ & $\mathbf{3 0 . 4 6}$ & $\mathbf{4 8 . 6 6}$ & $\mathbf{4 8 . 4 2}$ \\
\hline
\end{tabular}

Source: compiled from WDI 2012, GCI 2012.

RQ is regulatory quality; PHR is a measure of citizen participation and human rights

In the table above, the descriptive statistics used include: arable per person, the indicator of land used. Agricultural value added measures the percentage contribution of agricultural sector to the GDP. Net food export which serves as our measure of food security. Regulatory quality (RQ) measures the ability of government to formulate and implement sound policies and regulation and (PHR) which is a measure of citizen participation and human rights. As can be observed from the table, all the countries involved are net food importers except Cameroon. Likewise, as the ratio of arable land per person declines, the contribution of agricultural sector dwindles and the incidence of food insecurity heightened from 1998 to 2008. The increasing trend of food imports drains the current account balance in these economies; this worsens the level of food inflation which ultimately reduces real money income. As can be observed in figure 1, the growth rates of per capita incomes in selected countries was negative in 2008 and have been falling since 2010. 


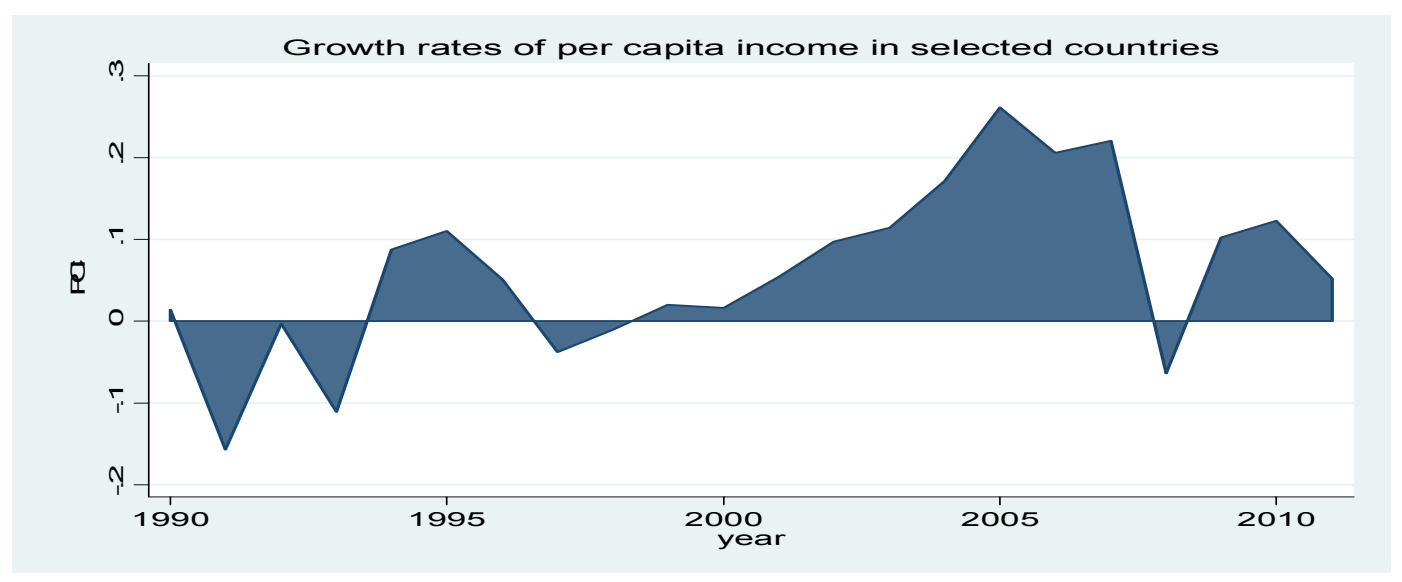

Figure 1. Growth rates of per capita income in selected countries

The weak institutional quality and the secrecy about how Africa government carryout land deals with foreign investors have raised lots of media concern. Table 3 presents major institutional framework, i.e. the competitive willingness of selected countries in their commitment to economic development. Most of these countries performed below world competitive average (see table $3 \& 4$ ).

According to Smaller and Mann (2009), the culture of secrecy that surrounds agricultural land deals raises concerns about government conduct in relation to issues of public interest. The lack of transparency undermines government accountability, and increases the opportunities for corruption and other inappropriate acts. It has potential implications for access to land, water and food for individuals and communities in areas subject to these contracts, impacting their human right to an adequate standard of living.

The nature of the negotiation processes and the level of consultations (coverage of interests to be represented in the deal) will be determined, to a large extent, by the (political) leaders in the host countries. These leaders may sometime join alliance with the local community leaders where such transactions will be made and by so, extract rent from the land deals. Sometimes, the stance to be eventually chosen by these leaders, in the negotiation process, will be guarded by the extent of economic rents that can be gotten from the foreign investors. Little wonder it has been reported that land investors make promises to the host communities and do not keep them because the institutional framework to enforce compliance are not adequately provided during negotiations and as a result land investors target mainly countries that have weak institutional framework (Cotula et al., 2009; Deininger et al., 2011; Oxfam International 2011).

Anseeuw et al., (2000), puts this in context by emphasising that there are four key failures of governance that brings about adverse consequences from LSFLDs. They observe that weak democratization in the form of deficit accountability, transparency, will contribute to elite capture of lands. The development of the legal system was also emphasised as poor legal structure will translate to poor property right protection and unjust dispossession of ancestral lands. 


\section{Macrothink}

Research in Applied Economics

ISSN 1948-5433

2014, Vol. 6, No. 4

Table 3. Trend of institutional variables in selected countries, 2012

\begin{tabular}{|c|c|c|c|c|c|c|c|c|c|}
\hline Country & $\begin{array}{c}\text { Property } \\
\text { rights }\end{array}$ & $\begin{array}{l}\text { Diversion } \\
\text { of public } \\
\text { fund }\end{array}$ & $\begin{array}{l}\text { Public trust } \\
\text { in politicians }\end{array}$ & $\begin{array}{l}\text { Irregular } \\
\text { payment } \\
\text { and bribes }\end{array}$ & favouritism & $\begin{array}{l}\text { Burden of } \\
\text { govt. } \\
\text { regulation }\end{array}$ & $\begin{array}{l}\text { Legal } \\
\text { framework } \\
\text { efficiency }\end{array}$ & $\begin{array}{l}\text { Govt } \\
\text { policy }\end{array}$ & $\begin{array}{l}\text { Ethical } \\
\text { behaviour }\end{array}$ \\
\hline Angola & 2.8 & 2.2 & 2.1 & 2.4 & 2.2 & 2.8 & 2.7 & 2.9 & 2.8 \\
\hline Cameroon & 3.8 & 2.0 & 2.1 & 2.8 & 2.4 & 3.4 & 3.3 & 4.3 & 3.5 \\
\hline DRC & -- & -- & -- & -- & -- & -- & -- & -- & -- \\
\hline Egypt & 3.7 & 2.5 & 2.8 & 3.4 & 3.0 & 3.2 & 3.2 & 3.9 & 4.1 \\
\hline Ethiopia & 3.7 & 3.2 & 3.1 & 3.1 & 2.8 & 3.4 & 3.6 & 3.5 & 3.2 \\
\hline Ghana & 4.2 & 3.1 & 2.9 & 3.3 & 2.9 & 3.5 & 4.1 & 4.1 & 3.7 \\
\hline Kenya & 3.9 & 3.0 & 2.7 & 3.2 & 2.8 & 3.6 & 3.9 & 3.9 & 3.8 \\
\hline Madagascar & 2.9 & 2.3 & 2.0 & 3.0 & 2.9 & 3.3 & 2.9 & 3.0 & 3.2 \\
\hline Malawi & 3.8 & 3.1 & 2.8 & 3.3 & 2.8 & 3.7 & 3.9 & 3.9 & 3.8 \\
\hline Mali & 3.3 & 2.3 & 2.3 & 2.3 & 2.5 & 3.4 & 3.1 & 3.4 & 3.5 \\
\hline Mozambique & 3.5 & 2.4 & 2.3 & 3.2 & 2.7 & 3.4 & 3.3 & 4.0 & 3.3 \\
\hline Nigeria & 3.4 & 1.9 & 2.1 & 2.6 & 2.2 & 3.5 & 3.6 & 3.7 & 3.2 \\
\hline Sierra Leone & 3.7 & 2.7 & 2.8 & 3.0 & 2.7 & 3.9 & 3.7 & 3.8 & 3.7 \\
\hline Sudan & -- & -- & -- & -- & -- & -- & -- & -- & -- \\
\hline Tanzania & 3.8 & 2.9 & 2.8 & 2.8 & 3.1 & 3.7 & 3.6 & 3.7 & 3.4 \\
\hline Zambia & 4.7 & 3.3 & 3.4 & 3.5 & 3.3 & 4.3 & 4.4 & 4.7 & 4.2 \\
\hline Average & 4.3 & 3.5 & 3.1 & 4.1 & 3.2 & 3.5 & 3.8 & 4.2 & 4.1 \\
\hline
\end{tabular}

Property rights measures how strong the protection of property rights is, including financial assets $[1=$ extremely weak; $7=$ extremely strong]. Diversion of public fund measures how common diversion of public funds to companies, individuals, or groups due to corruption occurs $[1=$ very commonly occurs; $7=$ never occurs $]$. Public trust in politicians measures the ethical standards of politicians $[1=$ extremely low; 7 = extremely high]. Irregular payments and bribes measures how common is it for firms to make undocumented extra payments or bribes connected with (a) imports and exports; (b) public utilities; (c) annual tax payments; (d) awarding of public contracts and licenses; (e) obtaining favourable judicial decisions. In each case, it ranges from 1 (very common) to 7 (never occurs). Favouritism in decision of government officials measures to what extent do government officials show favoritism to well-connected firms and individuals when deciding upon policies and contracts $[1=$ always show favoritism; $7=$ never show favoritism]. Burden of government regulation measures how burdensome is it for businesses to comply with governmental administrative requirements (e.g., permits, regulations, reporting) $[1=$ extremely burdensome; 7 = not burdensome at all]. Efficiency of legal framework in settling disputes measures how efficient is the legal framework for private businesses in settling disputes [1= extremely inefficient; 7 = extremely efficient]. Transparency of government policy making measures how easy is it for businesses to obtain information about changes in government policies and regulations affecting their activities? $[1=$ extremely difficult; $7=$ extremely easy]. Ethical behaviour of firms measures corporate ethics of companies (ethical behavior in interactions with public officials, politicians and other firms) [ 1 = extremely poor—among the worst in the world; 7 = excellent—among the best in the world] 
Table 4. Comparison of Institutional Quality in the Selected Countries and World Regions

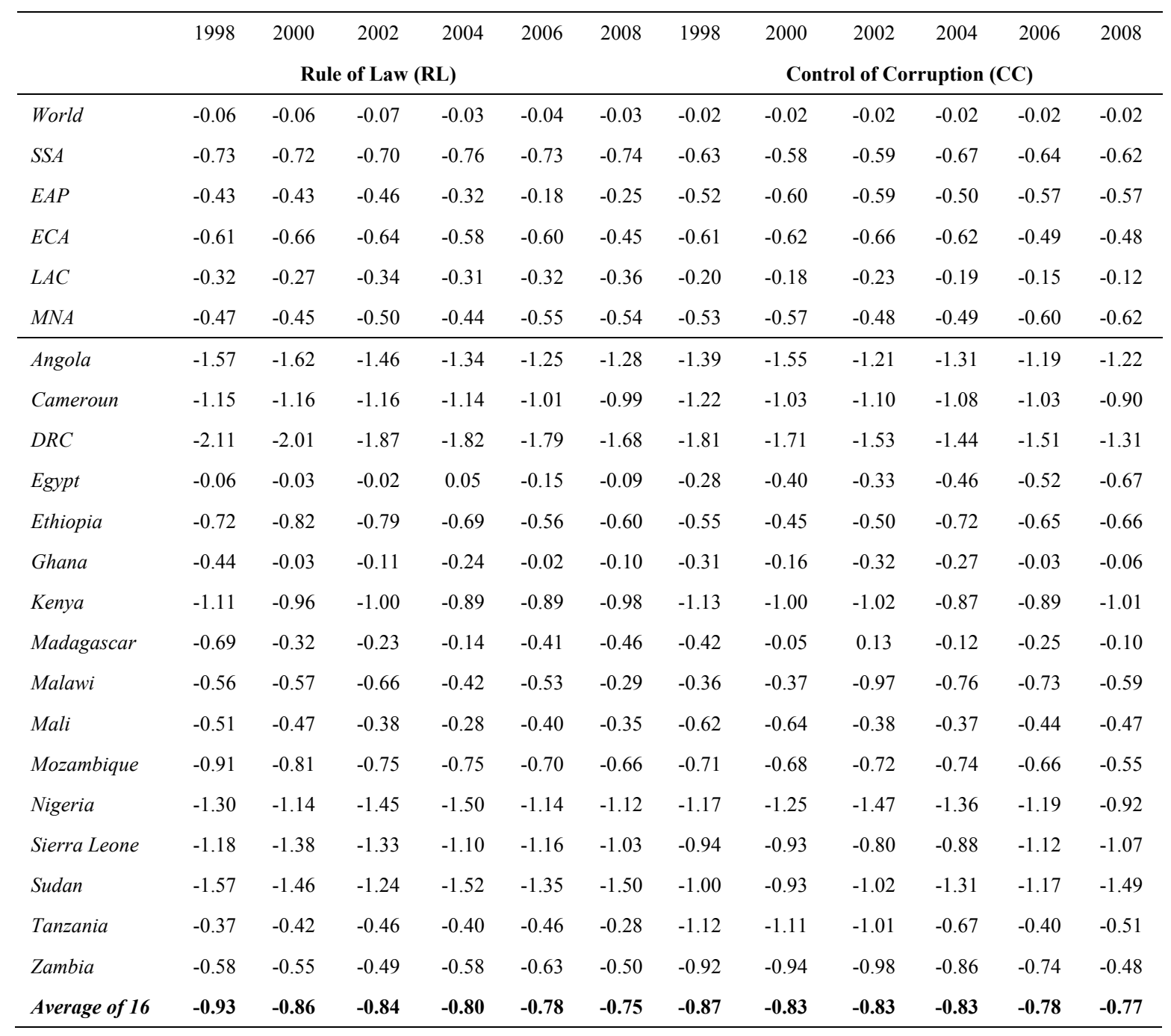

Note: The values ranges from -2.5 (worst) to 2.5 (best) i.e. the higher the better. EAP-East Asia and the Pacific; ECA-Europe and Central Asia; MNA-Middle East and North Africa; LAC-Latin America and Caribbean; SSA-Sub-Saharan Africa. The values for each region, including the world, are the averages for the respective region. This means the value of a representative country in for the respective region.

Source: Authors' compilation/computation using Data from African Development Indicators

At the demand for the land, negotiation process begins. However, the household who owns the land may not have the capacity for the negotiations process and most times, make use of the community leaders. These community leaders convey the desires of the household to the investors and at the same time act as an intermediary between the investors and the household. At this point, the role of public institutions comes to bear. This is based on their contributions to making policies that will regulate the negotiation processes such as land rights, private property protections and the likes and also, ensure that these policies are adhered by.

At this point, smooth negotiation process that upholds the desires of the land owners will be ensured. This is denoted with the straight line running from foreign investor, community leader and public officers via institutions to the negotiation process. From this process, agreement will be reached and then the outcome from such agreement will be ensured. This is 
denoted with the straight line from the negotiation process to the agreement and then the outcome. It is worth observing that a straight line runs from the outcome of the agreement to the household. This implies that when favourable agreements are reached from the negotiation process, foreign investors will uphold to such agreements, which will reflect in the livelihood of the household land owners. This is based on the strength of the institution and the commitment of public officers to ensure the realisation of the agreements.

On the contrary, foreign investors can liaise with community leaders and public officers to enter into agreement that will not yield any beneficial outcome for the household. This is denoted by the broken faint lines, running from foreign investor to community leaders and public officers. From the figure, it can be observed that the input of public officers flow to the negotiation process flow below institutions and policies. This implies that when foreign investors are able to liaise with public officers, then institutions in the form of policies and regulations are not brought to bear during the negotiation process. This goes for traditional leaders, who neglect the strong opinions of the household during the negotiation process. This is also denoted by the broken faint arrow. At this point, agreements are reached but such agreements do not translate into outcomes. Hence, no favourable positive effect on the household livelihood.

This assertion is in congruence with Anseuuw et al., (2000) who noted that foreign land investors target countries with poor institutional infrastructure. By this, they are able to find their way through and acquire more land. The broken and direct arrow flowing from/to foreign investor to/from other related investors signify a feedback mechanism that propel land rush.

\section{Theory and Methodology}

This study will draw from the framework of institutional theories for its analyses. Institutional quality has been noted to play important role in managing economic affairs after the seminal work of North. This is crucial as it is becoming increasingly obvious that economic agents that engage in economic transactions are not only influenced by economic factors but a number of other issues like institutions (Natal 2001; Meon and Sekkat 2008; Osabuohien 2011). Institutional framework can be defined as humanly formulated mechanism that has some measure of control on individuals in economic and social activities. It consists of informal measures such as sanctions, taboos, customs, and traditions as well as formal rules such as constitutions, laws, and property rights (North 1991; Acemoglu and Johnson 2008; Acemoglu and Robinson 2000). Institutions are usually put in place by humans to create peaceful habitation, reduce uncertainty in exchange of economic values, reduce the possibility of moral hazards and adverse selections.

Institutional framework can create choices that can affect transactions and production costs as well as the possibility of engaging in economic activities (Williamson 2000). It can reduce or increase transaction cost as it influences the nature of exchange. According to Matthews (1986), institutions have become a lively area in economics as it has brought economics more 
closely in touch with other disciplines in social sciences. Thus, institutions matter and the roles of institutions can be subjected to economic analysis within the purview of economic theory (Osabuohien 2011). The past decade has witnessed increased interest on the effects of institutions and policies in an economy as the relevance of economic environments such as secured property rights that is congruent to the development and efficient use of resources have been found to exert impacts on a country's economic growth and structural change (Cavalcanti et al., 2012). In other words, inappropriate institutional arrangements and policies in a country can lead to sub-optimal economic performance (Temple, 1999).

The hinging of the analyses in this study on the framework of institutional theories lies on the fact that land governance and deals will depend, to a considerable extent, on the prevailing institutional framework in the concerned countries (Osabuohien and Ike, 2011). The main theories of institutions are the New Institutional Economics (NIE) theory and LaPorta et al., (1999) theories of institutional development. The NIE theory is often seen as a new development in economic thoughts based on institutional economics and some of the principles of neo-classical economics (Natal 2001). The NIE theory has the maxim that economic activities engaged by individuals can be determined by some social and legal relationships existing among them. In this wise, NIE can be seen to embrace other areas outside the immediate domain of economics such as political science and sociology as well as the interaction that can be exerted on economic outcomes (Williamson 2000; Greif 2006). The basic assumptions of NIE include: assumptions on individuals; how and why individuals engage in a contract; and how individuals govern collective actions (Natal 2001).

Similarly, the LaPorta et al., (1999), theories of institutional development centre on the factors that can lead to the formation and persistence of a given institutional framework in a society. The theories of institutional development can be classified into three primarily based on their structural composition, namely: economic, political, and cultural institutional theories. The economic theory of institutional framework posits that institutions are fundamentally designed when it is efficient to create them. The implication of this is that institutions are mostly created by economic actors when the anticipated social benefits of creating them are significantly greater than the perceived transaction costs associated with their creation (Osabuohien 2011).

On the other hand, the political theory of institutional development as enunciated by LaPorta et al., (1999) is based on redistribution of societal resources much more than economic efficiency. The basic assumption of political institutional development theory is that institutions are designed by the (political) leaders that have (political) powers in manners that can enable them to extract economic rents from the society. The outcome of such tendency is usually conflicts of interests with regard to brawl of policy preferences, which can result to a number of inefficient public policies that are based on political logrolling and compensation of political allegiances instead of economic efficiency (Persson, Roland and Tabellini 1997; Adewole and Osabuohien 2007). The other type of institutional development theory is the cultural theory of institutional development. The cultural theory of institutional development postulates that a given society will usually hold beliefs that can shape collective actions of the constituting human agents. 
The political theory of institutional development seems to suitably fit into the discourse on LSFLDs as the nature of the negotiation processes, level of consultations, coverage of interests to be represented in the deal will be determined, to a large extent, by the (political) leaders in the host countries and in alliance with the local community leaders where such transactions will be made. The stance to be eventually chosen in the negotiation process will be guarded by the extent of economic rents that can be extracted from such land deals. Little wonder it has been reported that land investors make promises to the host communities and do not keep them because the institutional framework to enforce compliance are not adequately provided during negotiations and as a result land investors target mainly countries that have weak institutional framework (Cotula et al., 2009; Deininger et al., 2011; Oxfam International, 2011).

The model for the study is:

$$
\operatorname{lgdpc}=\alpha_{i t}+\operatorname{sap}_{i t}+\pi l a b_{i t}+\beta a g v a l_{i t}+\phi a g l n d_{i t}+\psi i n f l r_{i t}+\delta i n s t_{i t}+\varepsilon_{i t}
$$

In the equation one above, institutions may be endogenous in nature and may cause the problem of endogeneity in the model. In order to overcome the perceived challenge, the generalized method of moments is further used in the estimation process in addition to the ordinary least square. Therefore, equation one can be rewritten as:

$$
\operatorname{lgdpc}=\alpha_{i t}+\infty l g d p c_{i t}^{*}+\varphi k a p_{i t}+\pi l a b_{i t}+\text { Bagval }_{i t}+\phi a g l n d_{i t}+\psi i n f r_{i t}+\delta i n s t_{i t}+\varepsilon_{i t}
$$

Our measure of institutional framework inst is an index generated from voice and accountability, and government effectiveness. An additional variable was generated by the interaction of agricultural land and institutional quality, this becomes pertinent in order to control for the role of institutions in determining the effect of land acquisition on per capita income. The model involving the interacting variable is represented below:

$$
\begin{aligned}
\operatorname{lgdpc}=\alpha_{i t}+ & \infty \operatorname{lgdpc}_{i t}^{*}+\varphi \operatorname{kap}_{i t}+\pi l a b_{i t}+\beta a g v a l_{i t}+\phi a g l n d_{i t}+\psi \text { infl }_{i t}+\text { waglnd_inst }_{i t} \\
& +\varepsilon_{i t}
\end{aligned}
$$

\subsection{Method of analysis}

The study selects 16 countries in Africa where the issue of foreign land deals have been reported. It analysed the availability of land to agricultural production, agricultural value added and per capita income. Given the role of governance and institutions in the process of human relationship, the study also brought to bear in the analysis the issue of institutional quality using some indicators from world governance indicators. The econometric analysis adopted a panel data technique on the 16 countries for the period 1995-2012. The technique of estimation will be GMM due to the short panel structure as well as ability to handle the challenge of endogeneity as institutions may not be exogenous (Osabuohien, 2011; Meon and Sekkat, 2008; Acemoglu et al., 2005). 


\subsection{Discussion of results}

The econometric analysis performed is used as a supportive evidence to buttress the conclusions obtained from the stylized analysis. As can be seen from the results, the test statistics for the evaluation of the model, namely: AR(1), AR(2), Sargan and Wald indicate that the model was efficient and the estimate can be reliable. Prior to this estimation based on system GMM, a preliminary analysis was done using the Ordinary Least Squares (OLS), Fixed Effects (FE) and Random Effects (RE). However, this study focused on GMM estimates with a view to handle the possible challenge of endogeneity.

Table 5. Regression Result

\begin{tabular}{|c|c|c|c|c|c|c|}
\hline & (Ols) & (Ols) & $(\mathrm{Fe})$ & $(\mathrm{Fe})$ & (Gmm) & (Gmm) \\
\hline VARIABLES & Lgdpc & Lgdpc & $\operatorname{lgdpc}$ & $\operatorname{lgdpc}$ & $\operatorname{lgdpc}$ & $\operatorname{lgdpc}$ \\
\hline \multirow[t]{2}{*}{ Lkap } & $0.375^{* * *}$ & $0.363 * * *$ & $0.0789 * * *$ & $0.0824 * * *$ & $0.0304 * * *$ & $0.0313 * * *$ \\
\hline & $(0.0370)$ & $(0.0333)$ & $(0.0225)$ & $(0.0221)$ & $(0.00684)$ & $(0.00676)$ \\
\hline \multirow[t]{2}{*}{ Llab } & $-0.407 * * *$ & $-0.376^{* * *}$ & 0.228 & 0.552 & 0.0148 & $0.0263 *$ \\
\hline & $(0.0492)$ & $(0.0445)$ & $(0.568)$ & $(0.569)$ & $(0.0176)$ & $(0.0154)$ \\
\hline \multirow[t]{2}{*}{ Agval } & $-0.0268 * * *$ & $-0.0226^{* * *}$ & -0.00318 & -0.00235 & $-0.00210^{*}$ & $-0.00208^{*}$ \\
\hline & $(0.00257)$ & $(0.00242)$ & $(0.00249)$ & $(0.00246)$ & $(0.00116)$ & $(0.00118)$ \\
\hline \multirow[t]{2}{*}{ Aglnd } & $-0.00484 * * *$ & $0.129 * * *$ & -0.00978 & $0.0356^{*}$ & $0.000414 * *$ & $0.00858^{* * *}$ \\
\hline & $(0.00126)$ & $(0.0225)$ & $(0.00648)$ & $(0.0185)$ & $(0.000176)$ & $(0.00307)$ \\
\hline \multirow[t]{2}{*}{ Inflr } & $-0.000189 * * *$ & $-0.000110^{*}$ & $-6.16 \mathrm{e}-05^{* *}$ & $-5.43 e-05^{* *}$ & $-2.84 \mathrm{e}-06$ & $2.83 \mathrm{e}-06$ \\
\hline & $(6.71 \mathrm{e}-05)$ & $(6.17 \mathrm{e}-05)$ & $(2.55 \mathrm{e}-05)$ & $(2.51 \mathrm{e}-05)$ & $(8.82 \mathrm{e}-06)$ & $(9.38 \mathrm{e}-06)$ \\
\hline \multirow[t]{2}{*}{ Inst } & $0.450 * * *$ & $1.103^{* * *}$ & 0.0283 & $0.356^{* *}$ & $-0.0349^{*}$ & \\
\hline & $(0.109)$ & $(0.147)$ & $(0.0581)$ & $(0.138)$ & $(0.0179)$ & \\
\hline \multirow[t]{2}{*}{ aglnd_inst } & & $-0.0225^{* * *}$ & & $-0.00816^{* *}$ & & $-0.00137 * * *$ \\
\hline & & $(0.00380)$ & & $(0.00312)$ & & $(0.000498)$ \\
\hline \multirow[t]{2}{*}{ Year } & $-0.0176^{* *}$ & $-0.0203 * * *$ & 0.0103 & 0.000794 & $-0.00323 * * *$ & $-0.00364 * * *$ \\
\hline & $(0.00721)$ & $(0.00649)$ & $(0.0161)$ & $(0.0161)$ & $(0.000913)$ & $(0.000893)$ \\
\hline \multirow[t]{2}{*}{ L.lgdpc } & & & & & $0.950 * * *$ & $0.941 * * *$ \\
\hline & & & & & $(0.0155)$ & $(0.0147)$ \\
\hline \multirow[t]{2}{*}{ Constant } & $37.98^{* * *}$ & $39.12 * * *$ & -19.79 & -7.932 & $6.146^{* * *}$ & $6.605 * * *$ \\
\hline & $(14.25)$ & $(12.81)$ & $(23.51)$ & (23.44) & $(1.758)$ & $(1.684)$ \\
\hline Observations & 151 & 151 & 151 & 151 & 151 & 151 \\
\hline R-squared & 0.866 & 0.892 & 0.638 & 0.656 & & \\
\hline Number of id & & & 15 & 15 & 15 & 15 \\
\hline
\end{tabular}

Source: Computed using Stata 11.0.

Standard errors in parentheses, ${ }^{* * *} \mathrm{p}<0.01,{ }^{*} * \mathrm{p}<0.05,{ }^{*} \mathrm{p}<0.1$

From the available results in the table 5, the index of institutional framework was found significant. Likewise, agricultural land (proxy for land acquisition) was significant and exerts a positive effect on per capita income. With the inclusion of the interaction variable, agricultural land (aglnd) became highly positively significant in explaining variations in per capita income. This implies that agricultural land is correlated with per capita income, as 
more agricultural land is engaged, the living standard improves. This vividly portray the circumstance in developing Africa where a larger proportion of rural dwellers depend on agricultural trade and subsistence farming as their major source of income and livelihood respectively. Also, the impact magnitude of agricultural land on per capita income increases with the interaction variable (aglnd_inst).

The share of agriculture in GDP (agval) influences per capita income negatively, though significant. This implies that as the share of agriculture in GDP increases, per capita income is likely to fall. This outcome may not be unconnected with the jobless growth experience of the developing Africa, and the weak income earnings of agricultural commodities since agricultural produce are exported in its raw form. Also, the dismantle of marketing boards and recent international financialisation of commodities- which allows the prices of agricultural commodities to be determined in the financial markets of importers has a significant impediments on pricing options and income of farmers' in the producing countries.

Worthy of note, is the fact that labour force became only significant with the inclusion of the interaction variable. It hereby implies that without sound institutions, government and business activities can not contribute significantly to national wellbeing. This is evident in our sampled countries as the incidence of elitist capture of economic resources and weak bureaucratic activities is witnessed.

\section{Conclusion and Recommendation}

The study examines the incidence of large scale foreign land deals in Africa, considering majorly the 16 countries where cases of massive land acquisitions have been reported. It was evident that the biofuels boom that began in 2003 and the global food crisis of 2008 revived the strategy of foreign investors to purchase or secure long-term leases of land. Also, this latest investment strategy is more strongly driven by food and energy security rather than a notion of comparative advantage in the large-scale production of indigenous crops, which has been more characteristic of foreign-owned plantations since the end of the colonial era.

The study adopted the new institutional economic theory (NIE) and the generalized method of moment estimation techniques, though preliminary checks and estimation were conducted using the ordinary least square, fixed and random effect specifications. Our choice of GMM was based on the fact that institution was endogenous in our model; this obvious challenge was accounted for in order to obtain a robust and reliable estimates. An index of institutions was generated using an estimate of voice and accountability, and governance effectiveness using the principal regression component approach and the index was interacted with the proxy for land acquisition (agricultural land). This was necessary to ascertain the effect of role of institution in the relationship between land acquisition and per capita income.

The results from the empirical analysis show that agricultural land influences per capita income significantly. It hereby implies that as more agricultural land are cultivated; the wellbeing of the populace is likely to be enhanced primary through increased income for 
farmers, increase in real money income for non-farmers, drastic reduction in food inflation and exchange rate gains for the government. On the other hand, if the agricultural land are acquired for servicing the teaming population of investors country in terms of food, energy and biomass production; the host country tend to lose out completely with rising incidence of food insecurity, ethnic tension and clashes, food inflation resulting into falling real money income and current account depletion.

The study hereby recommends the strengthening of quality of institutions, as this has a strong bearing on competitiveness and growth. It as well influences investment decisions and the organization of production and plays a key role in the ways in which societies distribute the benefits and bear the costs of development strategies and policies. Though, the need for foreign investment to boost the agriculture sector cannot be over-emphasized, but institution has been adjudge to be pertinent in factor driven economies of the developing nations in order to avoid rest seeking behaviour of local and foreign stalk holders.

\section{References}

Acemoglu, D., \& Robinson, J. (2008). The Role of Institutions. Commission on Growth and Development Working Paper, No.10.

Adewole, M.A., \& Osabuohien, E.S.C. (2007). Analysis of Cost of Governance and Its Reduction Options in Nigeria. Nigerian Journal of Economic and Social Studies, 49(1), 137-159.

Barbier, E.B. (1997). The Economic Determinants of Land Degradation in Developing Countries. $\begin{array}{llll}\text { Philosophical Transactions. } & \text { Biological } & \text { Sciences, } & \text { 8999. }\end{array}$ http://dx.doi.org/10.1098/rstb.1997.0068

Braun, Joachim von \& Meinzen-Dick, Ruth (2011). "Land Grabbing” by Foreign Investors in Developing Countries: Risks and Opportunities. International Food Policy Research Institute (IFPRI) Policy Brief, 13.

Cavalcanti, T.V, Magalhaes, A.M., \& Tavares, J.A (2008). Institutions and Economic Development in Brazil. The Quarterly Journal of Economics and Finance, 48, 412-432. http://dx.doi.org/10.1016/j.qref.2006.12.019

Cotula, L. (2011). "Land Deals in Africa: What Is in the Contracts?" London (UK): International Institute for Environment (IIED), Retrieved from http://books.google.com/books?hl=en\&amp;lr=\&amp;id=CRX7vyKJpa4C\&amp;oi=fn $d \& a m p ; p g=P A 1 \& a m p ; d q=$ Land + deals + in + Africa $:+$ What $+i s+i n+$ the + contracts? \&am p;ots $=B M g s$ WTUQ4e\&amp;sig=NboIlLTQdY1BDGyhICU01lxiwww

Cotula, L., Vermeulen, S., Leonard, R., \& Keeley, J. (2009). Land Grab or Development Opportunity? Agricultural Investment and International Land Deals in Africa. London/Rome: IIED/FAO/IFAD. 
Deininger, K, Byerlee, D., Lindsay, J., Norton, A., Selod, H., \& Stickler, M. (2011). Rising Global Interest in Farmland. Washington DC: The World Bank. http://dx.doi.org/10.1596/978-0-8213-8591-3

Fian Report. (2010). Land Grabbing in Kenya and Mozambique. A report on two research missions and a human rights analysis of land grabbing. Willy-Branot-place, 69115, Heidelberg, Germany.

Friis, C., \& Reeberg, A. (2010). Land Grab in Africa: Emerging Land System Drivers in a Teleconnected World. Global Land Project Report No. 1

Global Competitive Index (2013)

Greif, A. (2006). Institutions and the Path to the Modern Economy: Lessons from Medieval Trade. Cambridge: University Press. http://dx.doi.org/10.1017/CBO9780511791307

Headey, D.D. (2010). Rethinking the Global Food Crisis. The Role of Trade Shocks. IFPRI Discussion Paper 00958. International Food Policy Research Institute.

International Food Policy Research Institute (2009). IFPRI IFPRI Policy Brief, No. 13.

Land Portal. (2011). Commercial Pressures on Land Retrieved from http://landportal.info/topic/commercial-pressures-land

LaPorta, R., Lopez-de-Silanes, F., \& Shleifer, A., Vishny, R. (1999). The Quality of Government. The Journal of Law, Economics and Organization, 15(1), 222-279. http://dx.doi.org/10.1093/jleo/15.1.222

Larbi, W.O., Antwi, A., \& Olomalaiye (2004). Computing Land Acquisition in GhanaPolicy and Praxis. Land Use Policy, 21(2), 115-127. http://dx.doi.org/10.1016/j.landusepol.2003.09.004

Li, T. M. (2011). Centering labor in the land grab debate. Journal of Peasant Studies, 281-298. http://dx.doi.org/10.1080/03066150.2011.559009

Mattingly, M. (1993). Urban Management Intervention in Land Markets. In: Managing Fast Growing Cities, New Approaches to Urban Planning and Management in the Developing World, N. Devas and C. Rokodi. Longman Scientific and Technical; England.

Matthews R.C.O. (1986). The Economic of Institutions and the Sources of Growth. The Economic Journal, 96(384).

Meon, P., \& Sekkat, K. (2008). Institutional Quality and Trade: Which Institutions? Which $\begin{array}{llll}\text { Trade. Economic } & \text { Inquiry, } & \text { 227-240. }\end{array}$ http://dx.doi.org/10.1111/j.1465-7295.2007.00064.x

Misra, B. (1991). Urban Land Markets in Asia: The Role of Private Developers and Guidelines on Public Acquisition of Land. Otaniemi: Japan. 


\section{Macrothink

Modie, A. (2011). AFRICA: "Universities must halt land grab investments" University World News. Retrieved from http://www.universityworldnews.com/article.php?story=2011062512292

Natal, A. (2001). The New Institutional Economics: A General Introduction. Decocumento De Disscusion Sobre El Neuvo Institucionalismo, 1, 4-21.

North, D. C. (1991). Institutions. The Journal of Economic Perspectives, 5(1), 97-112. http://dx.doi.org/10.1257/jep.5.1.97

Nyambara, P.S. (2001). Immigrants, "Traditional" Leaders and the Rhodesian State: The Power of Communal Land Tenure and the Policies of Land Acquisition in Gokwe, Zimbabwe, 1963-1979. Journal of Southern Africa Studies, 27(4), 771-791. http://dx.doi.org/10.1080/03057070120090736

Osabuohien, E.S (2011). Analysis of International Trade Performance in Selected SSA Countries: The Impact of Institutional Framework. Unpublished Ph.D Thesis Submitted to Department of Economics and Development Studies, Covenant University, Ota.

Osabuohien, E.S., \& Ike, D.N (2011). Economic Transformation and Institutional Framework in Nigeria-Lessons from Botswana and South Korea, Paper Presented at $52^{\text {nd }}$ Annual Conference of Nigerian Economic Society on Planning and the Transformation of the Nigerian Economy, Covenant University, Ota, Nigeria,13-15 ${ }^{\text {th }}$ September.

Osabuohein S. E., Ogundipe A. A., \& Efobi R. U. (2013). The Land Rush in Africa: Implications and Institutional Panacea. In: Okun, EE. and Asubonteng, K.O (ed)., Harnessing land and water resources for improved food security and ecosystem services in Africa. PP. 92-106

Oxfam International (2011). Growing a Better Future Food Justice in a Resource-constrained World, Oxford: Oxfam GB for Oxfam International.

Persson, T. Roland, \& G. Tabellini, G. (1997). Separation of Powers and Political Accountability. Quarterly Journal of Economics, 112, 310-327. http://dx.doi.org/10.1162/003355300555457

Skyner, L. (2001). Political Conflict and Legal Uncertainty: The Privatization of Land Ownership. Russia-Europe-Asia Studies, 53(7), 981-1000. http://dx.doi.org/10.1080/09668130120085001

Smaller, C., \& Mann, H. (2009). A Thirst for Distant Lands: Foreign Investment in Agricultural Land and Water. International Institute for Sustainable Development (IISD).

Temple, J. (1999). The New Growth Evidence. Journal of Economic Literature, 37, 112-156. http://dx.doi.org/10.1257/jel.37.1.112

UN. (2010). Foreign Land Purchase for Agriculture: What Impact on Sustainable Development? Sustainable Development Innovation Brief, 8. 


\section{Macrothink}

Research in Applied Economics

ISSN 1948-5433

2014, Vol. 6, No. 4

Williamson, O.E. (2000). The New Institutional Economics: Taking Stock, Looking Ahead. Journal of Economic Literature, 38(3), 595-613. http://dx.doi.org/10.1257/jel.38.3.595

World Bank (2011). Africa Development Indicators. Washington DC: The World Bank.

\section{Copyright Disclaimer}

Copyright for this article is retained by the author(s), with first publication rights granted to the journal.

This is an open-access article distributed under the terms and conditions of the Creative Commons Attribution license (http://creativecommons.org/licenses/by/3.0/). 